\title{
Comparison between Clothing Sizing Systems of Korean and Foreign SPA Brands for Clothing Size Satisfaction of Tall Women in their Twenties
}

\author{
Hye Suk Kim, So Hyun Kim, Han Ra Choi, and Yun Ja Nam ${ }^{1) \dagger}$ \\ Dept. of Textiles, Merchandising and Fashion Design, Seoul National University; Seoul, Korea \\ ${ }^{1)}$ Dept. of Textiles, Merchandising and Fashion Design/Research Institute of Human Ecology; \\ Seoul National University, Seoul, Korea
}

\begin{abstract}
The purpose of this study is to identify the differences between clothing size satisfaction and clothing sizing systems of Korean and foreign SPA (specialty retailer of private label apparel) brands according to height group, and provide foundation material that can be used to establish product strategy from the perspective of Korean SPA brand clothing sizes in order to secure competitiveness in the international market. Satisfaction of tall women in their twenties with the clothing sizes of SPA brands was researched, and t-test was conducted to examine differences between clothing size satisfaction of Korean and foreign SPA brands between the two height groups. Then, differences in the size minimum and maximum values, size ranges, size intervals and size numbers between clothing sizing systems of Korean and foreign SPA brands were researched and comparatively analyzed. Existing clothing sizes need to make improvements considering the lengths and shoulder width of tall consumers. And Korean SPA brands need to diversify the range and number of sizes in the clothing sizing system, and set a separate tall-size group, or apply the relationship between vertical and horizontal sizes of clothing to establish a clothing sizing system. A product strategy that applies the results of this study will solve the clothing size dissatisfaction of tall female consumers and stimulate sales of Korean SPA brand clothing products. The study has value in that it extracted realistic problems by researching clothing sizing systems of products that are actually sold.
\end{abstract}

Key words : SPA brand, tall woman, height, clothing size, clothing satisfaction

\section{Introduction}

The number of tall female consumers is increasing in the Korean apparel market (Korean Agency for Technology and Standards [KATS], 2013) due to an increase in the average height of Korean women (Min, 1986), and a tendency for the body types of women to become more westernized compared to the past. Amid this change, global SPA (specialty retailer of private label apparel) brands that are popular internationally are also strong in Korea, and global foreign SPA brands are recording high sales in the Korean apparel market (Kang, 2014). Korean clothing manufacturers have launched their own SPA brands (Sohn, 2013) to counteract to the threat of foreign SPA brands, with a differentiation strategy of cheaper prices, and sizes and designs that are more specialized for the body type of Korean people (Lee, 2014). However, tall Korean consumers are experiencing difficulties when selecting clothing size due to a clothing sizing system that does not reflect the changing height of consumers.

Therefore, in order to confirm the clothing size problems of Korean SPA brands regarding tall women, this study divided

†Corresponding author; Yun Ja Nam

Tel. +82-2-880-6844, Fax. +82-2-875-8359

E-mail: yunja.snu@hanmail.net women in their twenties according to height, and researched the clothing size satisfaction of Korean and foreign SPA brands. Women in their twenties were selected as the subjects of this study because most tall Korean women are in their twenties, at $69.5 \%$ (Lee, 2011a), and because women in their twenties are the main consumer group of SPA brands. Furthermore, this study researched the clothing sizing systems of Korean SPA brands and foreign SPA brands in order to understand the problems of clothing sizing systems of Korean SPA brands that target tall female consumers.

The goal of this study is to clearly identify the differences between clothing size satisfaction and clothing sizing systems of Korean and foreign SPA brands according to height group, and provide foundation material that can be used to establish product strategy from the perspective of Korean SPA brand clothing sizes in order to secure competitiveness in the competition with foreign SPA brands. A product strategy that applies the results of this study will solve the clothing size dissatisfaction of tall female consumers and stimulate sales of Korean SPA brand clothing products.

\section{Review of Literature}

2.1. Physical size changes of Korean women in their twenties 
There were rapid changes in Koreans' body shapes in around the 1960s due to changes in diet and lifestyle, and according to previous studies that examined the changes in body sizes and shapes of women in their twenties between 1990 and 1999 (Nam et al., 2002), the proportion of the lower body against height, back length, arm length, crotch length and waist height increased, and there were no significant changes for girths, excluding thigh girth and abdominal girth.

An examination of the changes in height of women in their twenties reported through Korean body measurement projects, Size Korea (KATS, 2013), show that the average height of those between 20 and 24 years of age increased by $4.9 \mathrm{~cm}$ and the average of those between 25 and 29 years of age increased by $5.1 \mathrm{~cm}$ from 1979 to 2010 . The $95 \%$ percentile height of women in their twenties in 1979 was $164.8 \mathrm{~cm}$ for the 20 24 years age group and $163.0 \mathrm{~cm}$ for the 25 29 years age group, but in 2010, it was 169.6 $\mathrm{cm}$ for the 20 24 years age group and $168.2 \mathrm{~cm}$ for the 25 29 years age group, and the ratio of tall women continuously increased during the period. In addition, the ratio of tall women, $170 \mathrm{~cm}$ tall or taller was $2.63 \%$ in 2004 , and increased to $3.11 \%$ in 2010 , showing that the ratio of women $170 \mathrm{~cm}$ or taller increased since the $2000 \mathrm{~s}$. This indicates continuous average height increase of female consumers in their twenties, and proportional increase of tall female consumers along with the average height increase.

\subsection{SPA brands}

SPA brands have a vertically integrated system where the company brands manufacture their own products and operate large directly-run stores to efficiently decrease manufacture and distribution cost and reduce the distribution stage to provide inexpensive clothing products (Jung, 2010; Knowledge economy terminology dictionary, 2010) with fast circulation (Lee \& Kang, 2004).

To keep in step with the rapid rise of SPA brands with global competitiveness and the globalization trend of the clothing industry (Cerviño, 1998), foreign SPA brands started to expand to the Korean apparel market in 2004 (Lee, 2014). In 2011, the market share of foreign SPA brands in the Korean apparel market was $5 \%$, but their growth rate was $77 \%$, which is in contrast to the average growth rate of the Korean fashion industry, which is $4.7 \%$ (Korea Federation of Textile Industries [KFTI], 2013). The increasing encroachment of foreign SPA brands in the Korean apparel market (Kim, 2013) is leading to a gradual decrease of market share for Korean clothing brands (Han, 2013), and Korean clothing brands are therefore in a stagnant stage (BNT News, 2013). In order to overcome this crisis situation, some Korean companies have launched SPA brands or are converting their existing brands into SPA brands ("Review 2013, preview 2014", 2013). However, the
2012 sales amount of Korean SPA brands Spao, Mixxo and 8Seconds was $30 \%$ of the Korean sales amount of foreign SPA brands Zara, Uniqlo and H\&M, making it difficult to judge whether they have succeeded as of yet. There is an opinion that Korean clothing brands need to become competitive global brands in order to compete with global foreign brands (Han, 2013).

An examination of the business strategy of global foreign SPA brands shows that Gap and Uniqlo are distribution-based SPA brands (Choi, 2001), providing easy casual designs with a clear concept (Lee, 2003; Lee \& Jung, 2010). They operate a supply system focusing on POS information (Onozuka, 2002) and through product planning to overcome the disadvantages of global outsourcing (Tex Herald, 2000) such as limitation of style and long lead time, and improve inventory circulation through an effective distribution system (Lee \& Jung, 2010). GAP considers the diversity of body shapes (Tex Herald, 2000) around the world and provides separate tall-size and petite-size lines (Gap, 2014) as part of their strategy to provide various sizes (Tex Herald, 2000). Uniqlo presents a small number of key items in a variety of colors and sizes but has an advertising strategy that focuses on just one product category (Lee, 2003). It also presents functional materials with high quality compared to the price (Lee, 2009a) through strategic collaborations with materials companies ("Uniqlo's second weapon", 2013; Yokota, 2012).

H\&M handles planning, distribution and sales through the headquarters, and outsources manufacture (Lee, 2002). The lead time of the H\&M supply system is 3 weeks, and new products are supplied 52 times a year, creating a fast product circulation rate. H\&M has excellent trend information power, and has an aggressive distribution network expansion strategy. Unlike Zara, which unifies stores around the world with one manual, H\&M considers local characteristics and materializes specialized local strategies, creating a strong distribution-bases brand characteristic ("Global era and global brand 'H\&M' in Sweden', 2004). H\&M is also famous for continuously conducting successful collaboration marketing with famous designers (Lee, 2010a), and executes profit donation promotions ("Global era and global brand 'H\&M' in Sweden", 2004) and an environment-preservation strategy (Lee, 2010b).

Zara is a manufacture-based SPA brand (Choi, 2001) with a vertically integrated strategy (Lopez \& Fan, 2009) that includes manufacture, planning, distribution and sales, and presents the latest trends and designs. The success factor of Zara is that it is sensitive to new trends, understands the new opinions and tendencies of society well, overcomes the differences between various races and culture, and shares a taste and sense for fashion ("Consideration of competitiveness", 2004). It reflects the reactions of customers in the field and immediately adjusts manufacture volume, manufac- 
tures small amounts of a variety of items (Yokota, 2012), and has a supply system with fast circulation (Lee, 2009b) through POS data. $70 \%$ of the product line changes once every two weeks ("Consideration of competitiveness", 2004), creating a strategy where the purchase desire of customers is stimulated through the scarcity value. Since the system does not create inventory, its strength is that only $10 \%$ of its total sales is affected by discounts (Yokota, 2012).

Foreign SPA brands thus have a clear brand concept, and an independent business strategy and system including the stages of planning, manufacture, distribution and sales. It appears that in order to compete with foreign SPA brands with global competitiveness, Korean SPA brands need to set independent and effective business strategies and create systems required to materialize the strategies.

Kim and Lee (2009) researched the marketing strategies Uniqlo and Zara used to enter the Korean apparel market, and Lee (2004) dealt with the marketing strategy of Korean SPA brands to consider ways to strengthen competitiveness with the advancement of foreign SPA brands to the Korean apparel market, and Kim (2012) compared the SPA brand marketing strategies of Korean and foreign brands. Lee (2013) said that Korean companies needed to counteract to the change through continuous research on changes in the Korean apparel market, training expert human resources, change and innovation at companies, and establishment of a vision for the Korean fashion industry. Chun and Noh (2006) stated that Korean women's and unisex casual brands have weak operation of large stores but short new product supply intervals, POS data and product development are actively applied for inventory management, and foreign manufacture is active for development of various products and maintenance of low cost. Regarding purchase actions of consumers, Kim and Lee (2007) said the main purchase motivation of SPA brands by Korean female university students is price and harmony with existing clothes, and that more weight should be placed on low price strategy products and separates, and that younger female university students place more importance on aesthetic characteristics rather than functionality.

Regarding clothing satisfaction of SPA brands, a study by Lee et al. (2012) stated that the recognized customer's satisfaction of SPA brands had a positive effect on brand loyalty. The study by Suh and Lee (2011) that compared the satisfaction of women in their twenties included clothing size diversity as one of the design elements of a product, but did not directly handle clothing size. Korean SPA brands were found to have lower satisfaction for design, price value and store policy compared to foreign SPA brands, and higher satisfaction for sales stimulation and management quality. It is difficult to find preceding studies that have researched clothing size appropriateness or clothing size satisfaction of SPA brands. Even if clothing satisfaction is handled, it is not handled independently. Therefore, the effects shown cannot be concluded to be due to clothing size alone. Therefore, there is a need for additional research on the clothing sizes of SPA brands, and considering the competitive situation in the clothing market, there is a need for a study that compares Korean and foreign SPA brands.

\subsection{Clothing size satisfaction}

Clothing size appropriateness is one of the important clothing characteristics that are considered when purchasing a clothing product (Jang, 2004). Most clothing products are manufactured based on average height and weight of consumers, so those who do not have an average size experience dissatisfaction with clothing size (Shim \& Kotsiopulos, 1990). Many studies on clothing size dissatisfaction of consumers who are not of average size focused on plus-size women (Chowdhary \& Beale, 1988; Kim, 2006; Kim, 2007; Lee, 2011c; Shim \& Kotsiopulos, 1990), and not many dealt with tall women (Jones \& Giddings, 2010; Kersch, 1984; Lee, 1997a).

Lee (1997b) said that tall women had the highest dissatisfaction about clothing size, and Jones and Giddings (2010) said tall women were dissatisfied about clothing size of misses-size clothes and had especially low satisfaction for pants. They claimed that while pants were purchased more from tall-size clothes, other categories were purchased more from misses-size clothes. Clothing products are failing to simultaneously satisfy style and size for tall female consumers. Clothing size is an important standard when choosing clothes for categories where clothing size is a serious problem, and style is more important when clothing size is acceptable. Kersch (1984) said that tall women are more satisfied with tall-size clothes than misses-size clothes, and claimed that there was a problem with clothing size because even tall-size clothes still had short lengths, big girths and big crotch lengths.

The study by Lee (1997a) found that clothing size satisfaction of Korean female university students $165 \mathrm{~cm}$ tall or taller was generally low at under the middle range. Satisfaction was lowest for pants, and this was found to be due to a failure to reflect the changes in lower body shape, which was becoming more westernized. Clothing size dissatisfaction was highest in order of sleeve length, clothing length, shoulder width, waist girth, hip girth, bust girth and back length. Tall women were thus found to be experiencing difficulties regarding size when purchasing clothes as their physical characteristics were not reflect in clothing product size.

According to preceding studies, there is a significant difference in clothing size dissatisfaction area according to height Lee (1997a), and height is an important area items that has a significant effect on clothing size satisfaction (Lee, 2011b). Lee (2011a) found 
that the reason behind clothing product size satisfaction difference according to height was due to physical characteristics, and clarified differences in the characteristics of body areas according to height. As a result of comparing the average height group of women in their twenties $155 \mathrm{~cm}$ to $165 \mathrm{~cm}$ tall and the tall group who are $165 \mathrm{~cm}$ or taller, based on 2010 Korean body measurement project measurements, Size Korea, the tall group had significantly higher measurements than the average height group for all heights, all girths, center front length and back length, leg length and shoulder width, while the index values of all heights and leg length to height were significantly higher, the index values of bust girth, hip girth and shoulder width to height were significantly lower, and the index values for waist girth, center front length and back length to height were similar.

As examined above, it is predicted that tall female consumers are dissatisfied with the clothing area items where they have big or small measurements compared to average height women. Existing studies on Korean women defined women $165 \mathrm{~cm}$ tall or taller as tall women, but even taller women are predicted to have more serious clothing size problems, so this is an area that requires clarification.

\subsection{Clothing sizing system}

In order to solve the clothing size dissatisfaction problem of tall women, there is a need to review and supplement the clothing sizing systems of clothing companies. The term clothing sizing system refers to a set body shape system based on deviation of body size (Glock \& Kunz, 1990), and clothing size markings are provided to provide information (Chun-Yoon \& Jasper, 1993) to consumers on whether the clothing corresponds with their physical size before they directly try on the clothes. Clothing size markings do not include the ease of the clothing, but present body size. Korean industrial standard KS K 0051 (2009) that defines the body size markings of women's wear require bust girth, hip girth and height for outerwear and blouses that need to fit well, bust girth and height for outerwear that does not need to fit well, bust girth for shirts, blouses, T-shirts and knitwear that do not need to fit well, waist girth and hip girth for pants and skirts that need to fit well, and waist girth for pants and skirts that do not need to fit well. The size intervals for clothes that need to fit well are $5 \mathrm{~cm}$ for height, and $3 \mathrm{~cm}$ for bust, waist and hip girth, and for clothes that do not need to fit well, are $5 \mathrm{~cm}$ for height, and $5 \mathrm{~cm}$ for bust, waist and hip girth.

An examination of preceding studies related to clothing sizing system show that Kim (1998) evaluated that the Korean industrial standard failed to reflect the westernized and diversified body shape changes of women in their twenties and studied the standard for a clothing sizing system for women in their twenties based on body measurements. Oh (2000) examined the clothing product size situation of women's wear brands and the clothing size problems of female consumers, extracted the gravity of the size problem for the hip area of bottoms, and claimed there was a need for a clothing sizing system that can cover an age range wider than the target age range of brands. Lee (2011a) who studied the physical characteristics of short women, stated that there is a need for a clothing sizing system that deals with various heights.

Existing studies on clothing sizing systems mainly focused on women in their twenties (Kim, 1998) or all adult women (Oh, 2000), and there were studies on middle-aged (Kim, 2000), elderly (Lee, 2000) and obese women (Ha, 2009; Kim, 2007) but there were not many that dealt with the clothing sizing system of tall women. The area items required to improve clothing sizing systems can be extracted through existing studies on clothing size satisfaction. The study by Jones and Giddings (2010) found that the misses-size systems were not appropriate for tall women to wear for all area items, and that a tall-size system was most needed for pants, but it did not deal with specific area items. The study by Lee (1997a) also found that the existing clothing sizing systems needed to be improved for all area items, and that there was a lack of size diversity for all area items excluding skirts. Also, the area items of clothing size dissatisfaction were pants width and pants length for pants, and bust girth and waist girth for T-shirts, which showed the biggest differences between different height groups. This indicated that the proportion of the upper body girth compared to leg length and height of tall women needed to be applied to the clothing sizing system.

Foreign SPA brands have already experienced consumers with a wide variety of body shapes as they have advanced to many different countries. In a situation where Korean SPA brands need to compete with foreign SPA brands, there is a need to confirm whether Korean brands have strong clothing sizing systems, and to supplement their product strategies. The increase of tall women in the Korean apparel market, as examined above, indicates that there is an increasing need of consumers for a clothing sizing system that is appropriate for tall women. A review of preceding study results show that the existing clothing sizing system cannot satisfy tall women, and therefore there is an urgent need to devise a clothing sizing system appropriate for tall women.

\section{Objectives}

The two objectives of this study were :

1) Clothing size satisfaction of tall women regarding Korean 
SPA brands and foreign SPA brands is examined through comparative analysis with a shorter group.

1-a) Differences in SPA brand preference and standards for clothing purchase between different height groups are examined.

1-b) Differences in SPA brand clothing size satisfaction according to clothing area is examined between different height groups.

1-c) Differences in Korean SPA brand and foreign SPA brand clothing size satisfaction according to clothing area are examined between different height groups.

2) The clothing sizing system of Korean SPA brands is examined through comparative analysis with foreign SPA brands.

2-a) Differences in clothing size marking methods between Korean SPA brands and foreign SPA brands are examined.

2-b) Differences in the size minimum and maximum values, size ranges, size intervals and size numbers for tops, skirts and pants between Korean SPA brands and foreign SPA brands are examined.

\section{Methods}

The first step conducted to solve the study problems above was to conduct a survey in November 2013, on 125 women in their twenties living in Seoul, with questions about their age, height, weight, size of tops they usually wear such as shirts or blouses (bust size), size of bottoms such as skirts and pants (waist size), SPA brand preference and standards when purchasing clothes, and clothing size satisfaction according to different clothing areas. The clothing area items used for the questions on clothing size satisfaction according to different clothing areas were shoulder width, front length, bust girth, waist girth, top length and sleeve length for tops, and waist girth, hip girth, skirt length, pants length and crotch length for bottoms. The subjects were asked to mark their satis- faction on a 5-point Likert scale (1) unacceptable fit; (2) poor fit; (3) acceptable fit; (4) good fit; (5) excellent fit, suggested by Bye and McKinney (2010).

Incomplete answers were eliminated, and data collected from 105 people were divided according to height into a group less than $170 \mathrm{~cm}$ tall (group A) and a group $170 \mathrm{~cm}$ tall or taller (group B). The average age of the survey subjects was 22.9 years, their average height was $165.9 \mathrm{~cm}$, their average weight was $52.5 \mathrm{~kg}$, and their average BMI was $19.1 \mathrm{~kg} / \mathrm{m}^{2}$. Weight and BMI of group A, who was a comparison group with tall women group, were averagely smaller than those of 20 29 age women group of Size Korea (2010), however were included in the range of standard deviation. Since the purpose of this study is focused on tall women, the ratio of tall women to total women in this study was higher than those of 20 29 age women group of Size Korea (Table 1).

Frequency analysis was conducted on the differences between SPA brand preference and clothing purchase standards of different height groups when purchasing clothes, and an independent sample t-test was conducted to examine differences between clothing size satisfaction of SPA brands between the two different height groups (group A and B). Additionally, in order to examine the clothing size problems of tall women in more detail, group B was divided into tall group of $170 \mathrm{~cm}$ tall or taller under $175 \mathrm{~cm}$ (group B1) and very tall group of $175 \mathrm{~cm}$ tall or taller (group B2). And then, indepth interviews were performed, divided into group B1 and group B2 with 7 of the subjects $170 \mathrm{~cm}$ tall or taller extracted from group B. The main in-depth interview questions were brand types preferred when purchasing clothes and reasons for preferences, inconveniences when purchasing clothes from Korea SPA brands and foreign SPA brands, clothing items that are difficult to purchase, and dissatisfactory clothing areas and reasons. Then, a matching sample t-test was conducted to examine clothing size satisfaction according to clothing area of Korean and foreign SPA brands

Table 1. Age, height, weight, BMI and tall women ratio of survey subjects

\begin{tabular}{|c|c|c|c|c|c|c|c|c|c|c|}
\hline \multirow{2}{*}{ Research } & \multirow{2}{*}{ Group category } & \multicolumn{2}{|c|}{ Age (years) } & \multicolumn{2}{|c|}{ Height $(\mathrm{cm})$} & \multicolumn{2}{|c|}{ Weight (kg) } & \multicolumn{2}{|c|}{ BMI $\left(\mathrm{kg} / \mathrm{m}^{2}\right)$} & \multirow{2}{*}{$\begin{array}{l}\text { Tall women } \\
\text { ratio }(\%)^{*}\end{array}$} \\
\hline & & Mean & SD & Mean & SD & Mean & SD & Mean & SD & \\
\hline \multirow{3}{*}{$\begin{array}{l}\text { This study } \\
\text { (2013) }\end{array}$} & Group A $(\mathrm{N}=71)$ & 23.1 & 1.31 & 161.8 & 4.23 & 50.4 & 4.07 & 19.2 & 1.39 & \multirow{3}{*}{32.38} \\
\hline & Group $B(N=34)$ & 22.5 & 2.09 & 174.7 & 3.71 & 57.2 & 5.56 & 18.7 & 1.57 & \\
\hline & Total & 22.9 & 1.62 & 165.9 & 7.26 & 52.5 & 5.56 & 19.1 & 1.46 & \\
\hline \multirow{3}{*}{$\begin{array}{l}\text { Size Korea } \\
\text { (2010) }\end{array}$} & $\begin{array}{l}20-24 \text { years age group } \\
\qquad(\mathrm{N}=108)\end{array}$ & - & - & 160.7 & 5.38 & 54.4 & 7.33 & 21.1 & 2.65 & \multirow{3}{*}{3.11} \\
\hline & $\begin{array}{l}25-29 \text { years age group } \\
\qquad(\mathrm{N}=100)\end{array}$ & - & - & 159.9 & 5.14 & 54.2 & 6.86 & 21.2 & 2.40 & \\
\hline & Total & - & - & 160.3 & - & 54.3 & - & 21.2 & - & \\
\hline
\end{tabular}

"The ratio of women who are $170 \mathrm{~cm}$ tall or taller to total women.

$\mathrm{BMI}=\left(\right.$ Weight $/$ Height $\left.^{2}\right) \times 10$ 
within the height groups.

Second, 4 Korean SPA brands and 4 foreign SPA brands that were found to be the most preferred by women subjects through the survey were selected. Data was collected from the size charts (8seconds, 2013; Forever21, 2013a; Forever21, 2013b; H\&M, 2013; Spao, 2013; Mixxo, 2013; Topten, 2013; Uniqlo, 2013; Zara, 2013) on their official websites and 3 stores in Seoul for each brand were visited ( 2 stores were visited if there were only 2 stores in Korea) for clothing sizing systems with three categories of tops, skirt and pants. It was found that the clothing sizing systems of jackets, coats, shirts, blouses, T-shirts and knits were generally similar within a brand so the tops were organized to include those items. This is why a brand uses consistent target consumers' body sizes. It was found that skirts and pants had different size ranges, intervals and numbers so bottoms were divided into skirts and pants. Though clothing sizing systems between formal pants and casual pants were similar, those of jeans were specific and different from those of other casual pants within a brand. Thus, clothing sizing systems of pants were investigated, including formal pants, casual pants and jeans and different results of jeans were noticed.

The minimum and maximum values, ranges, intervals and numbers of height and main girth sizes in the clothing sizing systems of Korean and foreign SPA brands were comparatively analyzed. The
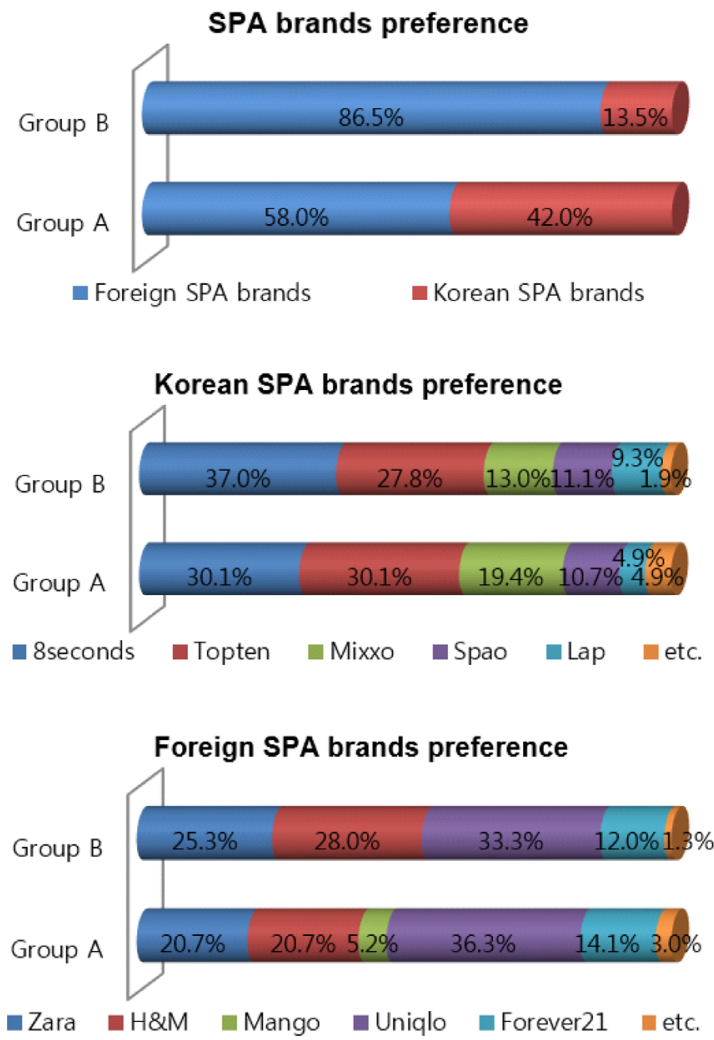

maximum value minus minimum value of height and main girth sizes within a brand becomes the size interval. The research for this study was limited to clothing products supplied to the Korean apparel market because size range can differ according to country for international brands.

\section{Results and Discussion}

\subsection{SPA brand clothing size satisfaction}

5.1.1. Differences in SPA brand preference and clothing purchase standard when purchasing clothes between different height groups

As a result of frequency analysis to examine the preference of SPA brands when purchasing clothes between height groups, $58.9 \%$ of group A said they preferred foreign brands, while $86.5 \%$ of group B said they preferred foreign brands. The standards for purchasing clothes for group A were in order of design, price and quality $(45.5,19.6,13.4 \%)$, and the standards for group B were in order of design, size and brand image (46.7, 23.3, 13.3\%). Both groups said design was the most important factor, but size was the second biggest factor for group $\mathrm{B}$, and this was the factor with the biggest difference between the two groups (B-A 15.3\%). In addi-
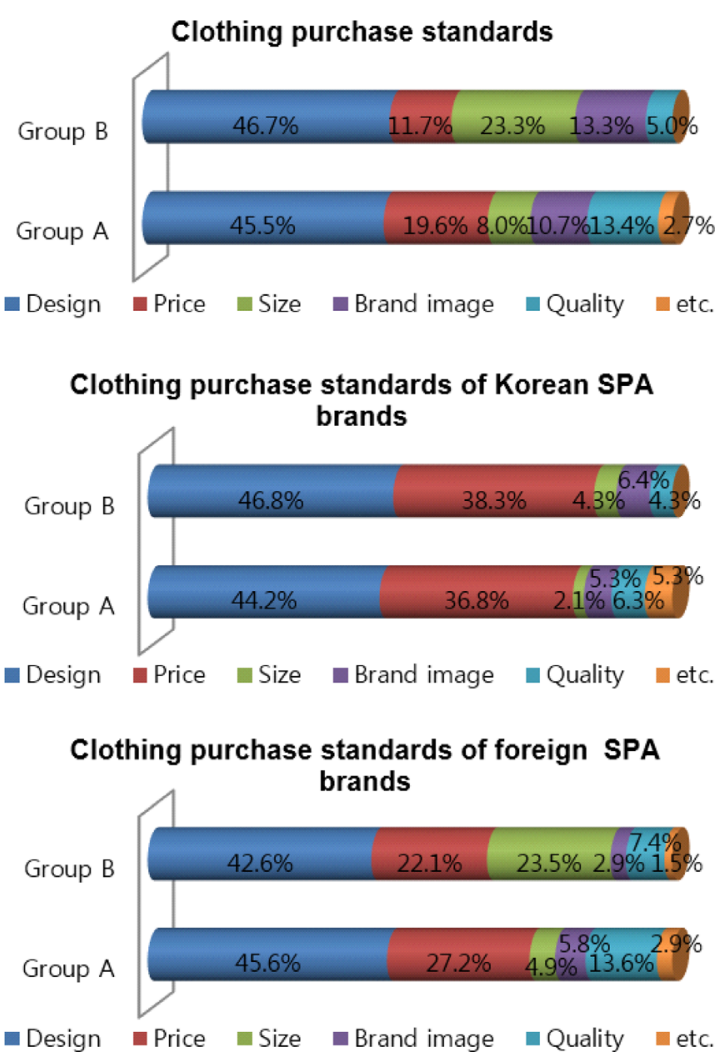

Fig. 1. SPA brand preference and clothing purchase standards of different height groups for clothing purchase. 
tion, both groups had the same order of preference of Korean brands - 8seconds, Topten, Mixxo, Spao (group A 30.1, 30.1, 19.4, $10.7 \%$; group B 37.0, 27.8, 13.0, 11.1\%) - and foreign brands Uniqlo, H\&M, Zara, Forever21 (group A 36.3, 20.7, 20.7, 14.1\%; group B 33.3, 28.0, 25.3, 12.0\%). The biggest standards for clothing purchase from their favorite brands were design and brand for Korean SPA brands for both groups, in the same order (group A 44.2, 36.8\%; group B 46.8, 38.6\%). However, the order was the same for foreign brands for group A (design 45.6, price 27.2, quality $13.6 \%$ ), but the order changed to design, size and price (42.7, $23.5,22.1 \%$ ) for group $\mathrm{B}$, and the size factor was the factor with the biggest difference between groups (B-A 18.7\%)(Fig. 1). Therefore, the analysis can be made that clothing size has an important effect on why tall women prefer foreign SPA brands.

5.1.2. Differences in SPA brand clothing size satisfaction according to clothing area between different height groups

As a result of an independent sample t-test to examine the differences in clothing size satisfaction according to clothing area between different height groups, there was a significant difference between groups for pants length, sleeve length, skirt length $(p<.001)$, and crotch length $(p<.01)$ for Korean brands. Group A was found to be more satisfied than group B about all the clothing areas above. There was a significant difference between groups for shoulder width and pants length $(p<.05)$ for foreign brands, and group B was more satisfied than group A about these clothing areas. For foreign brands, there was a significant difference between groups for shoulder width and pants length $(p<.05)$, and group B was more satisfied about these categories than group A. In sum, there were differences between groups in length rather than girth, and Korean brands had more clothing area items with differences between groups compared to foreign brands. Of all the clothing area items, the satisfaction of group B for the pants length, sleeve length and skirt length of Korean brands was significantly low (mean $=1.88,2.12,2.21$ ) and showed the clearest difference from group A (Table 2).

And then, women of $170 \mathrm{~cm}$ tall or taller (group B) was divided into tall women (group B1) and very tall women (group B2) in order to examine the clothing size problems of tall women in more detail. It was not appropriate to quantitatively analyze significant

Table 2. Differences in clothing size satisfaction according to clothing area between height groups

\begin{tabular}{|c|c|c|c|c|c|c|c|}
\hline \multirow{2}{*}{$\begin{array}{c}\text { Brand } \\
\text { category }\end{array}$} & \multirow{2}{*}{$\begin{array}{l}\text { Tops or } \\
\text { bottoms }\end{array}$} & \multirow{2}{*}{ Area item } & \multicolumn{2}{|c|}{ Group A $(\mathrm{N}=71)$} & \multicolumn{2}{|c|}{ Group B $(\mathrm{N}=34)$} & \multirow{2}{*}{$\mathrm{t}$-value } \\
\hline & & & Mean & S.D. & Mean & S.D. & \\
\hline \multirow{11}{*}{ Korea } & \multirow{6}{*}{ Tops } & Shoulder width & 3.20 & 0.821 & 2.94 & 0.694 & 1.664 \\
\hline & & Interscye width & 3.20 & 0.821 & 3.21 & 0.641 & -0.059 \\
\hline & & Bust girth & 3.14 & 0.867 & 3.12 & 0.769 & 0.139 \\
\hline & & Waist girth & 3.15 & 0.804 & 3.35 & 0.597 & -1.414 \\
\hline & & Top length & 3.18 & 0.833 & 2.88 & 0.729 & 1.887 \\
\hline & & Sleeve length & 3.17 & 0.810 & 2.12 & 0.946 & $5.575^{* * *}$ \\
\hline & \multirow{5}{*}{ Bottoms } & Waist girth & 3.11 & 0.728 & 2.97 & 0.834 & 0.850 \\
\hline & & Hip girth & 3.07 & 0.781 & 2.76 & 0.855 & 1.763 \\
\hline & & Skirt length & 3.20 & 0.729 & 2.21 & 0.914 & $5.537^{* * *}$ \\
\hline & & Pants length & 2.75 & 0.874 & 1.88 & 0.946 & $4.488^{* * *}$ \\
\hline & & Crotch length & 3.07 & 0.816 & 2.59 & 0.857 & $2.739^{* *}$ \\
\hline \multirow{11}{*}{ Foreign } & \multirow{6}{*}{ Tops } & Shoulder width & 3.20 & 0.768 & 3.56 & 0.660 & $-2.489^{* *}$ \\
\hline & & Interscye width & 3.18 & 0.780 & 3.41 & 0.821 & -1.357 \\
\hline & & Bust girth & 3.18 & 0.683 & 3.18 & 0.904 & 0.038 \\
\hline & & Waist girth & 3.15 & 0.768 & 3.26 & 0.828 & -0.651 \\
\hline & & Top length & 3.23 & 0.741 & 3.32 & 0.843 & -0.580 \\
\hline & & Sleeve length & 3.03 & 0.878 & 2.97 & 1.218 & 0.276 \\
\hline & \multirow{5}{*}{ Bottoms } & Waist girth & 2.96 & 0.801 & 3.00 & 1.015 & -0.213 \\
\hline & & Hip girth & 3.04 & 0.783 & 3.09 & 0.830 & -0.271 \\
\hline & & Skirt length & 3.06 & 0.754 & 2.91 & 1.026 & 0.815 \\
\hline & & Pants length & 2.58 & 0.822 & 3.06 & 1.043 & $-2.363^{*}$ \\
\hline & & Crotch length & 3.00 & 0.828 & 3.00 & 0.888 & 0.000 \\
\hline
\end{tabular}

${ }^{*} p<.05,{ }^{* *} p<.01,{ }^{* * *} p<.001$ 
difference in clothing size satisfaction between group B1 and group B2 because of small number of subjects each group. Instead, 7 subjects were selected from group B for in-depth interviews.

As a result of in-depth interviews, group B1 was more dissatisfied about tops than bottoms, and said the biggest problem when purchasing clothes was that the sleeve length and top length were too short. They said they often could not purchase dresses or tops because the length was too short, and bottoms were short too at times, but it was not a big problem. Group B1 mostly purchased their clothes at department stores or foreign SPA brands, and said they relatively preferred foreign SPA brands because of the cheap cost and trendy designs.

Group B2, the very tall group, showed different results. They said that not just sleeve length and top length, but also bottoms length was a big problem. Most of B2 said they preferred foreign SPA brands and many said European SPA brand clothing sizes fit them well. They were found to place importance on trendy designs, but ended up with a preference for foreign SPA brands ultimately because of clothing size. They said that general Korean brands and Korean SPA brands had limited designs tall women could wear, while foreign SPA brands provide more diverse designs and appropriate clothing sizes for tall women. There was also an answer that
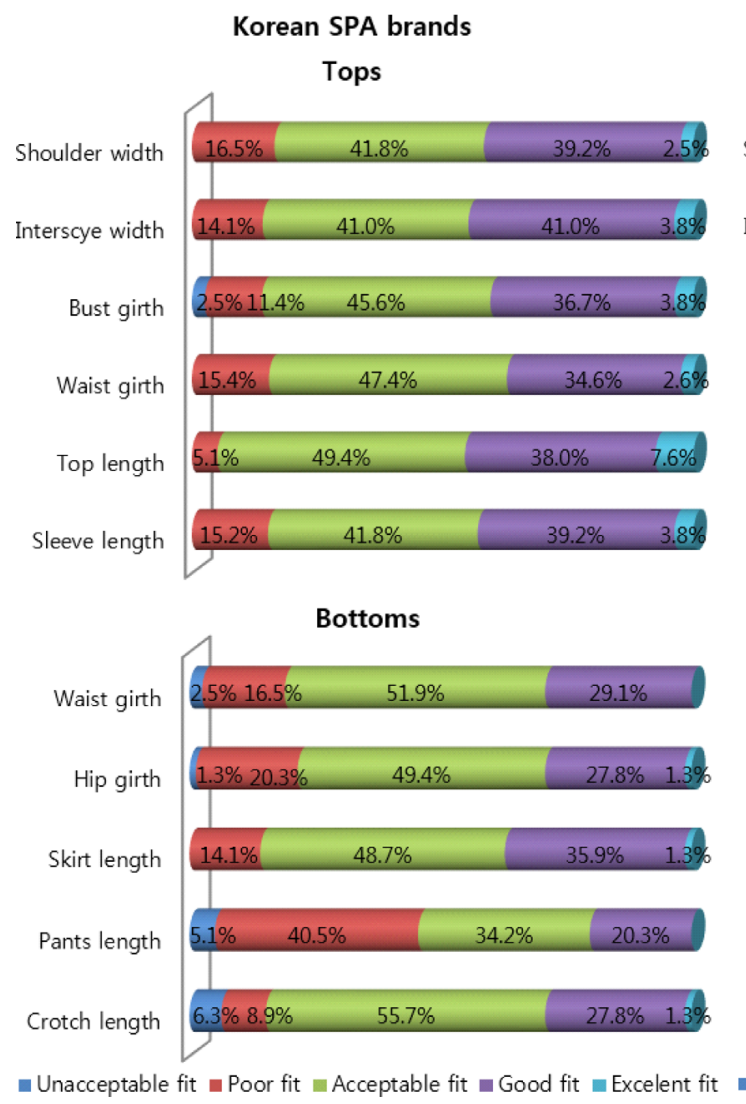

a subject did not purchase clothes if the size did not fit, even if they liked the design, indicating that clothing size is an important clothing purchase factor for very tall women.

Very tall consumers in group B2 were thus found to experience clothing size problems in bottoms length in addition to top length, and this is especially similar to the research results of Jones and Giddings (2010) that there was low satisfaction of clothing size for pants. Clothes cannot be purchased if the size does not fit, so clothing size appropriateness is a decisive clothing purchase factor for very tall women. The problem with Korean SPA brands discovered here is that there is a lack of designs with diverse clothing sizes compared to foreign SPA brands. Thus, there is a lack of assortment of products.

5.1.3. Differences in clothing size satisfaction of Korean and foreign SPA brands within height groups

As a result of examining the percentages of the answers 'poor fit' and 'unacceptable fit', which show dissatisfaction from the clothing size satisfaction survey of SPA brands according to clothing area, group A was dissatisfied with pants length for both Korean and foreign brands (45.6, 59.3\%)(Fig. 2). Group B was dissatisfied in order of pants length (72.2\%), sleeve length (71.4\%),

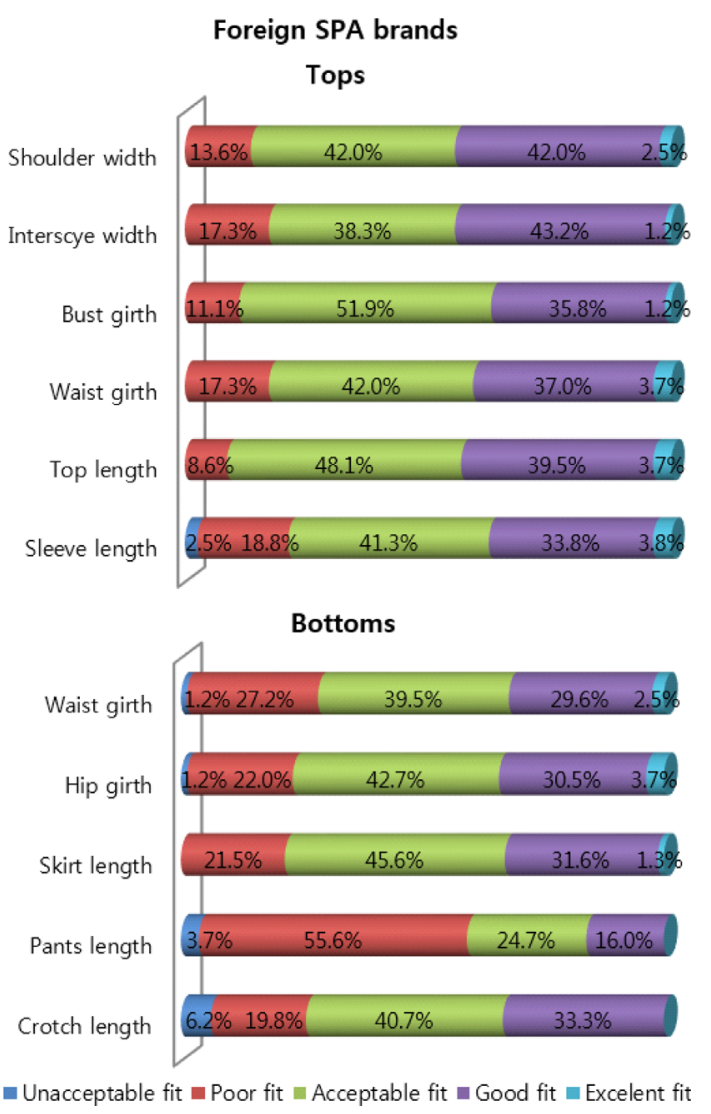

Fig. 2. SPA brand clothing size satisfaction according to clothing area of height group A. 


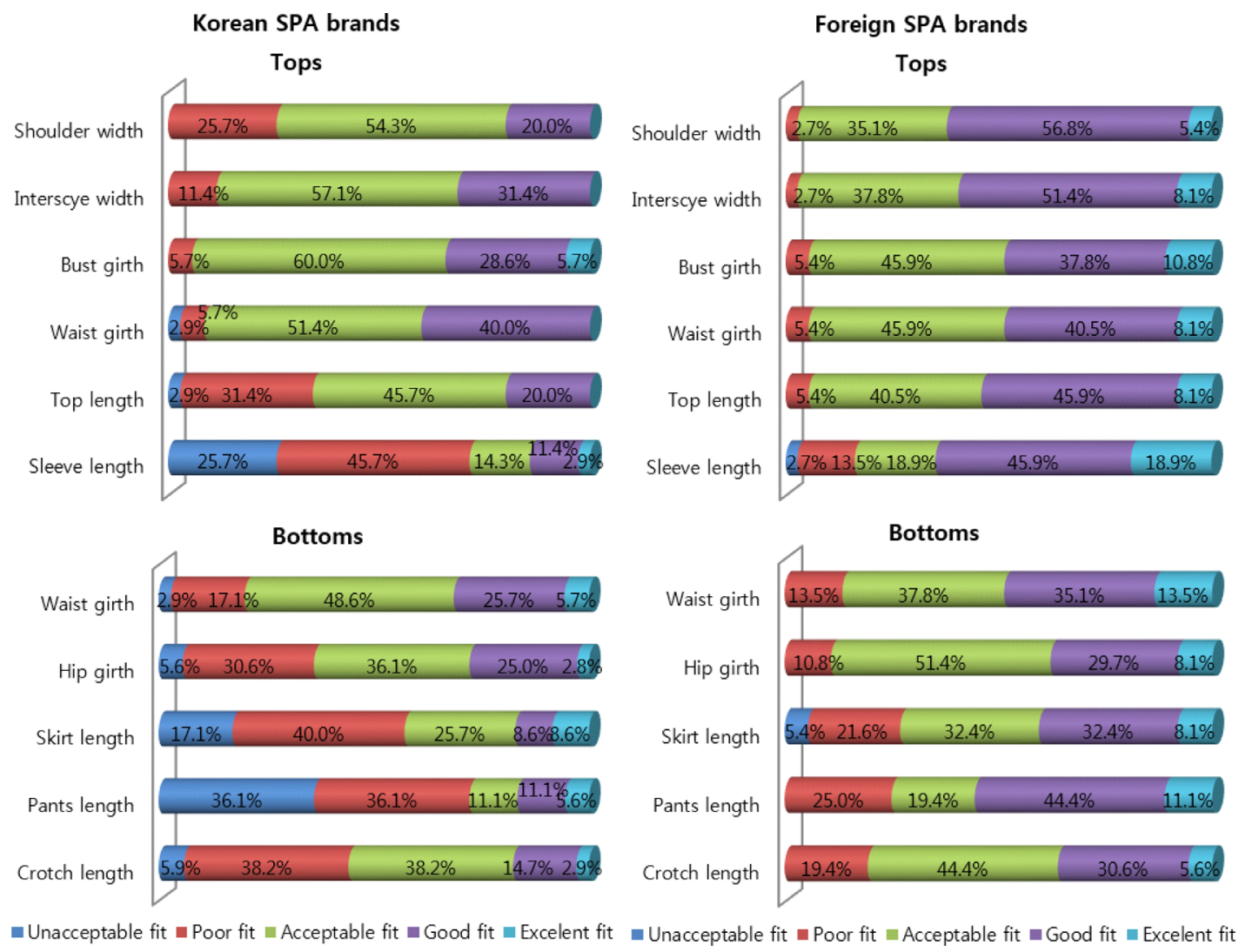

Fig. 3. SPA brand clothing size satisfaction according to clothing area of height group B.

skirt length (57.14\%) and crotch length (44.12\%) for Korean brands, and dissatisfied in order of skirt length $(27.0 \%)$ and pants length (25.0\%) for foreign brands (Fig. 3). The dissatisfaction was much lower for foreign brands than Korean brands. This shows that tall female consumers are dissatisfied more about clothing areas of Korean brands than foreign brands, and are dissatisfied more about clothing areas related to bottoms than tops.

As a result of a matching sample t-test to examine the clothing size satisfaction differences of Korean and foreign SPA brands according to clothing area between different height groups, group A had no clothing area items with a significant difference between Korean and foreign brands. Group B showed significant differences between Korean and foreign brands for pants length, shoulder width $(p<.001)$, skirt length, sleeve length, crotch length $(p<.01)$, and top length $(p<.05)$, and the average satisfaction was higher for foreign brands than Korean brands for all of the clothing areas. Group A did not feel any difference in satisfaction between clothing sizes of Korean and foreign brands, but group B appears to be more satisfied with foreign brand sizes, mainly for length items (Table 3). Therefore, the analysis is made that this difference in clothing size satisfaction has led to tall female consumers preferring foreign SPA brands over Korean SPA brands.
As a result of a matching sample t-test to examine the clothing size satisfaction differences of Korean and foreign SPA brands according to clothing area between different height groups, group A had no clothing area items with a significant difference between Korean and foreign brands. Group B showed significant differences between Korean and foreign brands for pants length, shoulder width $(p<.001)$, skirt length, sleeve length, crotch length $(p<.01)$, and top length $(p<.05)$, and the average satisfaction was higher for foreign brands than Korean brands for all of the clothing areas. Group A did not feel any difference in satisfaction between clothing sizes of Korean and foreign brands, but group B appears to be more satisfied with foreign brand sizes, mainly for length items (Table 3). Therefore, the analysis is made that this difference in clothing size satisfaction has led to tall female consumers preferring foreign SPA brands over Korean SPA brands.

The results of the survey and in-depth interviews show that the problem of Korean SPA brand clothing products that needs attention is the relationship between the vertical and horizontal clothing sizes that do not fit tall women. The height of the survey subjects and their top and bottom sizes cannot be seen as a proportional relationship, and consumers were found to desire clothing sizes that fit their body well regardless of their height. Meanwhile, the problem 
Table 3. Differences in clothing size satisfaction of Korean and foreign SPA brands according to clothing area within each height group

\begin{tabular}{|c|c|c|c|c|c|c|c|c|c|c|c|}
\hline \multirow{3}{*}{$\begin{array}{l}\text { Tops or } \\
\text { bottoms }\end{array}$} & \multirow{3}{*}{ Area item } & \multicolumn{5}{|c|}{ Group A $(\mathrm{N}=71)$} & \multicolumn{5}{|c|}{ Group $B(\mathrm{~N}=34)$} \\
\hline & & \multicolumn{2}{|c|}{ Korean SPA brands } & \multicolumn{2}{|c|}{ Foreign SPA brands } & \multirow{2}{*}{ t-value } & \multicolumn{2}{|c|}{ Korean SPA brands } & \multicolumn{2}{|c|}{ Foreign SPA brands } & \multirow{2}{*}{ t-value } \\
\hline & & Mean & S.D. & Mean & S.D. & & Mean & S.D. & Mean & S.D. & \\
\hline \multirow{6}{*}{ Tops } & Shoulder width & 3.20 & 0.821 & 3.20 & 0.768 & 0.000 & 2.94 & 0.694 & 3.56 & 0.660 & $-4.408^{* * *}$ \\
\hline & Interscye width & 3.20 & 0.821 & 3.18 & 0.780 & 0.103 & 3.21 & 0.641 & 3.41 & 0.821 & -1.314 \\
\hline & Bust girth & 3.14 & 0.867 & 3.18 & 0.683 & -0.382 & 3.12 & 0.769 & 3.18 & 0.904 & -0.360 \\
\hline & Waist girth & 3.15 & 0.804 & 3.15 & 0.768 & 0.000 & 3.35 & 0.597 & 3.26 & 0.828 & 0.594 \\
\hline & Top length & 3.18 & 0.833 & 3.23 & 0.741 & -0.388 & 2.88 & 0.729 & 3.32 & 0.843 & $-2.520^{*}$ \\
\hline & Sleeve length & 3.17 & 0.810 & 3.03 & 0.878 & 1.080 & 2.12 & 0.946 & 2.97 & 1.218 & $-3.510^{*}$ \\
\hline \multirow{5}{*}{ Bottoms } & Waist girth & 3.11 & 0.728 & 2.96 & 0.801 & 1.893 & 2.97 & 0.834 & 3.00 & 1.015 & -0.197 \\
\hline & Hip girth & 3.07 & 0.781 & 3.04 & 0.783 & 0.270 & 2.76 & 0.855 & 3.09 & 0.830 & -1.644 \\
\hline & Skirt length & 3.20 & 0.729 & 3.06 & 0.754 & 1.276 & 2.21 & 0.914 & 2.91 & 1.026 & $-3.603^{* *}$ \\
\hline & Pants length & 2.75 & 0.874 & 2.58 & 0.822 & 1.445 & 1.88 & 0.946 & 3.06 & 1.043 & $-6.159^{* * *}$ \\
\hline & Crotch length & 3.07 & 0.816 & 3.00 & 0.828 & 0.66 & 2.59 & 0.857 & 3.00 & 0.888 & $-3.230^{* *}$ \\
\hline
\end{tabular}

with Korean SPA brands is that the horizontal clothing size increases as the vertical clothing size increases, because the pattern grading rule that taller height leads to bigger girths and widths is applied in the clothing manufacturing stage. Tall women purchase clothes based on the horizontal size of clothes, so the length does not fit and this leads to a low clothing size satisfaction. The problem between vertical and horizontal clothing size is apparent with shoulder width, too. There was a significant difference in clothing size satisfaction of foreign brand shoulder width between height groups, and there was a clear difference between Korean and foreign brands for group B. Thus, it seems there is an urgent need for Korean brands to revise their grading rule for shoulder width. This result coincides with the result from the study by Lee (2011a) where tall women have significantly small index values of bust girth, hip girth and shoulder width to height.

Another point to focus on is that the average clothing size satisfaction of Korean brands was 3.11 for group A and 2.73 for group $\mathrm{B}$, and that of foreign brands was 3.06 for group A and 3.16 for group B. Both Korean and foreign brands had a satisfaction level that was less than middle level. The clothing size satisfaction of foreign brands is not excellent either, so if Korean brands develop clothing sizes and patterns appropriate for the body types of Korean women, it could induce purchases by tall female consumers. Experience of clothing size and pattern development for the Korean apparel market will aid efforts for a product strategy that reflects local body types when Korean brands advance to international markets.

\subsection{SPA brand clothing sizing systems}

5.2.1. Differences in size marking methods of Korean and for- eign SPA brands

As a result of examining the size marking methods of Korean and foreign SPA brands, the size information presented through offline and online channels were different. The size markings on clothing labels provided through offline channels used two of either $\mathrm{cm}$, inches or S-M-L for Korean brands. Mixxo was the only brand where the height was marked on the care label. Spao did not mark $\mathrm{cm}$ on tops or skirts at all, which is expected to cause inconveniences for clothing purchases. Foreign brands marked two or more methods out of 34-36-38(EUR), 4-6-8(US), 26-28-30(MEX), S-M$\mathrm{L}$, inches or $\mathrm{cm}$. The neck label or care label marked the height and major girth sizes in cm, making it easy to check the size when making a purchase and allowing consumers to make clear size predictions. However, Uniqlo is the only foreign brand that does not mark height (Table 4). Foreign brands also mark the main girth category of bust girth for tops and waist girth for bottoms. None marked the hip girth. Mixxo was the only brand out of the 8 brands that marked hip girth on the clothing label. None of the Korean brands marked sizes in other country standards on the clothing labels. 8seconds only provided EUR, US and UK sizes through their website. Out of the foreign brands, Uniqlo was the only brand that did not mark other country sizes. H\&M marked EUR, US, CA, MX and CN sizes, Zara marked EUR, USA, Mex, UK and IT sizes, and Forever 21 marked EU, US, CA, MX, UK, KR, JP and CN sizes on the clothing labels.

A review of the size marking methods provided through online channels shows that Korean and overseas brands all provide a size chart through their official websites. No problems were discovered with foreign brands, but for Korean brands, the size intervals on the size chart were different from the size intervals marked on the 
Table 4. Size marking methods of SPA brands on clothing labels through offline channels

\begin{tabular}{|c|c|c|c|c|c|c|c|c|}
\hline \multirow{2}{*}{$\begin{array}{l}\text { Clothing } \\
\text { category }\end{array}$} & \multicolumn{4}{|c|}{ Korean SPA brands } & \multicolumn{4}{|c|}{ Foreign SPA brands } \\
\hline & 8seconds & Topten & Mixxo & Spao & Uniqlo & $\mathrm{H} \& \mathrm{M}$ & Zara & Forever 21 \\
\hline Tops & $\begin{array}{c}\text { S-M-L, } \\
\mathrm{cm}^{*} \\
\text { (bust girth) }\end{array}$ & $\begin{array}{c}\mathrm{cm} \\
\text { (bust girth) }\end{array}$ & $\begin{array}{l}\text { S-M-L, cm* } \\
\text { (height, } \\
\text { bust girth, } \\
\text { hip girth) }\end{array}$ & S-M-L & $\begin{array}{l}\text { S-M-L, cm* } \\
\text { (bust girth) }\end{array}$ & $\begin{array}{c}\text { 34-36-38 (EUR), } \\
\text { 4-6-8 (US), S-M-L, } \\
\text { cm (height, bust girth) }\end{array}$ & $\begin{array}{c}\text { S-M-L, 26-28-30 } \\
\text { (MEX), cm* (height, } \\
\text { bust girth) }\end{array}$ & $\begin{array}{l}\text { S-M-L, cm } \\
\text { (height, bust } \\
\text { girth) }\end{array}$ \\
\hline Skirts & $\begin{array}{c}\text { S-M-L, } \\
\mathrm{cm}^{*} \\
\text { (bust girth) }\end{array}$ & $\begin{array}{c}\mathrm{cm} \\
\text { (waist girth) }\end{array}$ & $\begin{array}{l}\text { inch, cm* } \\
\text { (height, } \\
\text { bust girth, } \\
\text { hip girth) }\end{array}$ & S-M-L & $\begin{array}{l}\text { S-M-L, cm* } \\
\text { (waist girth) }\end{array}$ & $\begin{array}{c}\text { 34-36-38 (EUR), } \\
\text { 4-6-8 (US), S-M-L, } \\
\text { cm (height, waist } \\
\text { girth) }\end{array}$ & $\begin{array}{l}\text { S-M-L, 26-28-30 } \\
\text { (MEX), cm* (height, } \\
\text { waist girth) }\end{array}$ & $\begin{array}{l}\text { S-M-L, cm } \\
\text { (height, waist } \\
\text { girth) }\end{array}$ \\
\hline Pants & $\begin{array}{c}\text { S-M-L, } \\
\text { cm* } \\
\text { (bust girth) }\end{array}$ & $\begin{array}{c}\mathrm{cm} \\
\text { (waist girth) }\end{array}$ & $\begin{array}{l}\text { inch, } \mathrm{cm}^{*} \\
\text { (height, } \\
\text { bust girth, } \\
\text { hip girth) }\end{array}$ & $\begin{array}{l}\mathrm{cm} \\
\text { (waist girth), } \\
\text { inch }\end{array}$ & $\begin{array}{l}\text { inch, cm } \\
\text { (waist girth), } \\
\text { S-M-L }\end{array}$ & $\begin{array}{l}\text { 34-36-38 (EUR), } \\
\text { 4-6-8 (US), } \\
\mathrm{cm} \text { (height, waist } \\
\text { girth) }\end{array}$ & $\begin{array}{l}\text { 34-36-38 (EUR), } \\
\text { 4-6-8 (USA), 26-28- } \\
30 \text { (MEX), cm* } \\
\text { (height, waist girth) }\end{array}$ & $\begin{array}{l}\text { inch, cm } \\
\text { (height, waist } \\
\text { girth) }\end{array}$ \\
\hline
\end{tabular}

This table shows the size marking methods researched through clothing labels of offline channels that are actually supplied in the Korean apparel market. $\mathrm{cm}^{*}$ If marked on care label.

Mixxo's hip girth for tops is only used for jacket, T-shirts and knits.

actual clothes for Topten, and Mixxo only provided a vague clothing sizing system that showed whether S-M-L was 55-66-77. Therefore, there were found to be cases where Korean brands provided a more ambiguous size chart to consumers compared to foreign brands.

Korean brands are failing to clearly relay height and major girth size information to offline channel consumers who have to depend on clothing labels for clothing size information compared to foreign brands, and to provide the size information of different countries for international sales. Therefore, there is a need to improve the size marking methods. Korean and foreign brands were both discovered to have limitations of failing to provide specific size information such as hip girth on their clothing labels. It appears there is a need for brands to make efforts to improve purchase convenience by providing size information consumers can understand clearly and easily.

5.2.2. Differences in size ranges, intervals and numbers of Korean and foreign SPA brands

As a result of investigating the minimum and maximum values, ranges, intervals and numbers of height and main girth sizes provided by Korean and foreign SPA brands in the Korean apparel market, the size ranges of Korean brands was $155 \sim 170 \mathrm{~cm}$ for height, 85 100 cm for bust girth and 89 101.5 cm for hip girth; the size intervals were mainly $5 \mathrm{~cm}$ for height, bust girth and hip girth; and there were 2 3 sizes (Tables 5, 6 and 7). Mixxo was the only Korean brand with a $3 \mathrm{~cm}$ interval for T-shirts and knits, and Spao did not provide height or hip girth size, even on its website. The size ranges of foreign brands were $153 \sim 175 \mathrm{~cm}$ for height, 76 104 $\mathrm{cm}$ for bust girth and $84 \sim 112 \mathrm{~cm}$ for hip girth; the size intervals were mainly $5 \mathrm{~cm}$ for height, and 3, 4 and $6 \mathrm{~cm}$ for bust and hip girth; with some sizes maintaining a 0 size interval for height as the size grew; and there were cases where the size intervals after $\mathrm{M}$ or $\mathrm{L}$ size were twice the size of size intervals of smaller sizes. There were 2 4 height sizes, and 3 5 bust and hip girth sizes (Tables 5, 6 and 7). An examination of the minimum and maximum size range values showed that the height size ranges ere similar, but Korean brands provided narrower girth size ranges than foreign brands (Table 6). Uniqlo covered only up to $166 \mathrm{~cm}$ in height and had the shortest height size, and Zara was the only brand that covered up to $175 \mathrm{~cm}$ in height. The size range of Uniqlo's bust and hip girths was $27 \mathrm{~cm}$, which were the biggest size ranges, and the size range of Spao was the smallest, at $10 \mathrm{~cm}$ for bust girth. Topten provided the weakest size number, as it only had 2 sizes, and Zara and H\&M provided up to 4 height sizes. H\&M and Uniqlo provided the most girth sizes, with up to 5 sizes (Table 7).

For skirts, the size range of Korean brands was $155 \sim 170 \mathrm{~cm}$ for height, 64 95 cm for waist girth and 89 101 cm for hip girth, and the size interval was $5 \mathrm{~cm}$ for height and $5 \mathrm{~cm}$ for waist and hip girths, with only Mixxo using a girth size interval of $3 \mathrm{~cm}$. They had 2 4 sizes (Tables 5, 6 and 7). Foreign brands had heights from $153 \sim 175 \mathrm{~cm}$, waist girths from $76 \sim 104 \mathrm{~cm}$, and hip girths from $84 \sim 112 \mathrm{~cm}$, and the size intervals were mainly $5 \mathrm{~cm}$ for height and $3,4 \mathrm{~cm}$ for waist and hip girths; with some sizes maintaining a 0 size interval for height as the size grew; and there were cases where the size intervals after $\mathrm{M}$ or $\mathrm{L}$ size were bigger than the size intervals of smaller sizes. There were $3 \sim 4$ height sizes, and $3 \sim 5$ waist and hip girth sizes (Tables 5, 6 and 7). An examination of the minimum and maximum size range values showed that Korean brands provided narrower girth size ranges than foreign brands (Table 5). 
Uniqlo covered a height range of 149 166 cm, and Zara covered the tallest height. It was the only brand that covered up to $175 \mathrm{~cm}$ in height. Judging by the heights covered by the tops and bottoms sizing systems, Zara appears to be comparatively focusing on tall consumers, while Uniqlo is focusing on short consumers. The size range of Uniqlo's height, and waist and hip girths were 17, 18 and $18 \mathrm{~cm}$ each, making it the biggest ranges, and the waist girth size range of Forever 21 was also $18 \mathrm{~cm}$, while the height, waist girth and hip girth of 8seconds was the smallest, at 5, 6 and $6 \mathrm{~cm}$. $8 \mathrm{sec}-$ onds and Topten provided the weakest number of sizes, as they only had 2 sizes, and Zara, H\&M and Forever21 provided up to 4 height sizes. H\&M and Uniqlo provided the most girth sizes, with up to 5 sizes, and Mixxo was the Korean brand that provided the most, with up to 4 sizes (Table 7).

For pants, including jeans, the size range of Korean brands was $160 \sim 170 \mathrm{~cm}$ for height, $64 \sim 79 \mathrm{~cm}$ for waist girth and $89 \sim 102 \mathrm{~cm}$ for hip girth, and the size interval was $5 \mathrm{~cm}$ for height and $3 \mathrm{~cm}$ for waist and hip girths, with only Topten using a girth size interval of $5 \mathrm{~cm}$ for waist and hip girths. They had 2 4 sizes (Tables 5, 6 and 7). Foreign brands had heights from $149 \sim 175 \mathrm{~cm}$, waist girths from 56 $80 \mathrm{~cm}$, and hip girths from $81 \sim 104 \mathrm{~cm}$, and the size intervals were mainly $5 \mathrm{~cm}$ for height, and $3,4,5 \mathrm{~cm}$ for waist and hip girths, and 2, 2.5, 3 and $4 \mathrm{~cm}$ for waist and hip girths for jeans; with some sizes having a bigger interval after $\mathrm{M}$ and $\mathrm{L}$ than smaller sizes for general pants, but each brand maintaining their own size interval for jeans. There were 3 4 height sizes, and 3 5 waist and hip girth sizes for general pants, and $4 \sim 9$ waist and hip girth sizes for jeans (Tables 5, 6 and 7). An examination of the minimum and maximum size range values showed that Korean brands provided narrower girth size ranges than foreign brands (Table 5). Three of the foreign brands, excluding Uniqlo, all covered up to $170 \mathrm{~cm}$, and while the waist and hip girth size ranges of Uniqlo and H\&M were the biggest at $20 \mathrm{~cm}$, the waist girth size ranges of 8 seconds and Topten were the smallest at $9 \mathrm{~cm}$, and they provided the weakest number of sizes, as they only had 2 3 sizes. Zara, H\&M and Forever21 provided up to 4 height sizes. Uniqlo, Forever 21 and H\&M provided up to 9, 7 and 6 girth sizes, respectively, and out of the Korean brands, Spao provided up to 5 girth sizes (Table 7).

It was discovered that there was a difference between the size ranges and numbers of the size charts provided by brands and those of the apparel products actually sold. The foreign brands provided a size chart covering the wide range of international sizes through their websites, but the size ranges of the clothes sold in Korea were much narrower. This was because bigger sizes are not distributed to Korea as there are comparatively less plus-size consumers in the Korean market. There was also a difference between the size number in the size chart provided by Korean brands and the size num- ber actually sold. Unlike the reason for foreign brands, Korean brands did not manufacture the bigger sizes at all or did not have them in stock for all categories, in many cases.

As examined above, Korean brands have a smaller size ranges than foreign brands, and the size intervals are bigger and the size numbers are smaller. For pants, especially jeans, foreign brands provide segment the sizes for each product, and there is a big difference in size diversity between Korean and foreign brands. For skirts, the size problem appeared to be serious for Korean brands as there was a brand that only had 2 sizes. Therefore, the evaluation can be made that the reason tall women were found to be less satisfied with clothing size about Korean brands than foreign brands in the clothing size satisfaction survey is due to the lack of a diversified clothing sizing system. Thus, Korean brands need to increase their size numbers and ranges to secure diverse sizes.

Considering just height, Zara appears to be providing the most advantageous clothing sizing system for tall women. However, foreign SPA brands do not operate separate petite-size or tall-size sections, and Uniqlo, Zara and Forever21 had bigger intervals between sizes after $\mathrm{M}$ and $\mathrm{L}$ than for the smaller sizes, so there is not a high chance that when tall women purchase clothes according to their height, the body girths will fit them, too. Thus, it can be predicted that the foreign brands investigated have clothing sizes more appropriate for women with big girths rather than tall women, and that they do not fulfill the needs of tall women to an excellent standard yet. However, it is worth noting that many brands, including Gap, are making strategical efforts to establish a clothing sizing system that applies various body proportions. Therefore, Korean SPA brands will need to actively provide a product line that applies body proportions, or improve their current clothing sizing system by adding sizes that can cover tall women's body length. Applying the relationship between body lengths and girths of the target consumer to the pattern grading rule will be necessary for such improvements.

Additionally, Korean SPA brands tended not to adhere to the regulation concerning fit degree to the body in KS K 0051. Traditional apparel brands generally have the consistency of fit degree to the body according to the brand identity. For the characteristic of SPA brand such as the variety of style, SPA brands can go on some products with tight fit and other products with loose fit depending on style. In this study, it was examined that Korean SPA brands use unorganized size intervals. In case of 8 seconds, the size intervals were $3 \mathrm{~cm}$ for girth items of pants although $5 \mathrm{~cm}$ for those of tops and skirts. In case of Mixxo, the size intervals of certain inner items were $3 \mathrm{~cm}$ while those of other items were $5 \mathrm{~cm}$ (Table 6). The intention of standards is to support the efficiency and advance of industry. Therefore, it is required to establish dual size intervals by 
Table 5. Size minimum and maximum values, and size ranges of SPA brands

(Unit : cm)

\begin{tabular}{|c|c|c|c|c|c|c|c|c|c|}
\hline \multirow{3}{*}{$\begin{array}{l}\text { Clothing } \\
\text { category }\end{array}$} & \multirow{3}{*}{ Area item } & \multicolumn{4}{|c|}{ Minimum and maximum value of size } & \multicolumn{4}{|c|}{ Size range } \\
\hline & & \multicolumn{2}{|c|}{ Korean SPA brands } & \multicolumn{2}{|c|}{ Foreign SPA brands } & \multicolumn{2}{|c|}{ Korean SPA brands } & \multicolumn{2}{|c|}{ Foreign SPA brands } \\
\hline & & Min. & Max. & Min. & Max. & Min. & Max. & Min. & Max. \\
\hline \multirow{3}{*}{ Tops } & Height & 155 & 170 & 153 & 175 & 10 & 15 & 10 & 15 \\
\hline & Bust girth & 85 & 100 & 76 & 104 & 10 & 15 & 14 & 27 \\
\hline & Hip girth & 89 & 101.5 & 84 & 112 & 6 & 12.5 & 14 & 27 \\
\hline \multirow{3}{*}{ Skirts } & Height & 155 & 170 & 149 & 175 & 5 & 15 & 15 & 17 \\
\hline & Bust girth & 64 & 95 & 57 & 79 & 6 & 10 & 16 & 18 \\
\hline & Hip girth & 89 & 101 & 82 & 106 & 6 & 9 & 15.5 & 18 \\
\hline \multirow{3}{*}{ Pants } & Height & 160 & 170 & 149 & 170 & 10 & 10 & 5 & 17 \\
\hline & Bust girth & 64 & 79 & 56 & 80 & 9 & 13 & 12 & 20 \\
\hline & Hip girth & 89 & 102 & 81 & 104 & 9 & 12.5 & 12 & 20 \\
\hline
\end{tabular}

This table is limited to clothing products actually supplied to the Korean apparel market.

Table 6. Size intervals of SPA brands

(Unit : cm)

\begin{tabular}{|c|c|c|c|c|c|c|c|c|c|}
\hline \multirow{2}{*}{$\begin{array}{l}\text { Clothing } \\
\text { category }\end{array}$} & \multirow{2}{*}{ Area item } & \multicolumn{4}{|c|}{ Korean SPA brands } & \multicolumn{4}{|c|}{ Foreign SPA brands } \\
\hline & & 8 seconds & Topten & Mixxo & Spao & Uniqlo & $\mathrm{H} \& \mathrm{M}$ & Zara & Forever21 \\
\hline \multirow{3}{*}{ Tops } & Height & 5 & 5 & 5 & - & 0,6 & 0,5 & 5 & 5 \\
\hline & Bust girth & 5 & 5 & $3^{* *}, 5$ & 5 & 3,6 & 4 & 4,8 & 6 \\
\hline & Hip girth & 5 & 5 & $3^{* *}$ & - & 3,6 & 4 & 4,8 & 6 \\
\hline \multirow{3}{*}{ Skirts } & Height & 5 & 5 & 0,5 & - & 4,6 & 0,5 & 5 & 0,5 \\
\hline & Bust girth & 5 & 5 & 3 & 5 & 3,6 & 4 & 4,8 & 5,7 \\
\hline & Hip girth & 5 & 5 & 3 & - & 3,6 & 4 & 4,8 & 5,7 \\
\hline \multirow{3}{*}{ Pants } & Height & 5 & 5 & 0,5 & - & 4,6 & 0,5 & 0,5 & 0,5 \\
\hline & Bust girth & 3 & 5 & 3 & 3 & $2.5^{*}, 3,6$ & 4 & 4 & $2^{*}, 3^{*}, 5,7$ \\
\hline & Hip girth & 3 & 5 & 3 & - & $2.5^{*}, 3,6$ & 4 & 4 & $2^{*}, 3^{*}, 5,7$ \\
\hline
\end{tabular}

This table is limited to clothing products actually supplied to the Korean apparel market.

*If jeans size intervals are different.

${ }^{* *}$ The interval is only used for T-shirts and knits

Table 7. Size numbers of SPA brands

(Unit : PCs)

\begin{tabular}{|c|c|c|c|c|c|c|c|c|c|}
\hline \multirow{2}{*}{$\begin{array}{l}\text { Clothing } \\
\text { category }\end{array}$} & \multirow{2}{*}{ Area item } & \multicolumn{4}{|c|}{ Korean SPA brands } & \multicolumn{4}{|c|}{ Foreign SPA brands } \\
\hline & & 8seconds & Topten & Mixxo & Spao & Uniqlo & $\mathrm{H} \& \mathrm{M}$ & Zara & Forever 21 \\
\hline \multirow{3}{*}{ Tops } & Height & 3 & 2 & 3 & - & 2 & $3-4$ & $3-4$ & 3 \\
\hline & Bust girth & 3 & 2 & 3 & 3 & $3-5$ & $3-5$ & $3-4$ & 3 \\
\hline & Hip girth & 3 & 2 & 3 & - & $3-5$ & $3-5$ & $3-4$ & 3 \\
\hline \multirow{3}{*}{ Skirts } & Height & 2 & 2 & 2 & - & 3 & $3-4$ & $3-4$ & $3-4$ \\
\hline & Bust girth & 2 & 2 & $3-4$ & $2-3$ & $3-5$ & $3-5$ & $3-4$ & $3-4$ \\
\hline & Hip girth & 2 & 2 & $3-4$ & - & $3-5$ & $3-5$ & $3-4$ & $3-4$ \\
\hline \multirow{3}{*}{ Pants } & Height & $2-3$ & $2-3$ & 2 & - & 3 & 4 & 2 & $3-4$ \\
\hline & Bust girth & $2-3$ & $2-3$ & $3-4$ & $3-5$ & $5,7-9^{*}$ & 6 & $3-4$ & $3-4,5-7^{*}$ \\
\hline & Hip girth & $2-3$ & $2-3$ & $3-4$ & - & $5,7-9^{*}$ & 6 & $3-4$ & $3-4,5-7^{*}$ \\
\hline
\end{tabular}

This table is limited to clothing products actually supplied to the Korean apparel market.

*If number of jeans sizes are different. 
style or unified size interval for brand concept in the process of planning of apparel products.

\section{Conclusions}

This study examined the clothing size problems of Korean SPA brands for tall women by confirming the clothing size satisfaction of Korean and foreign SPA brands between different height groups and the differences in clothing sizing systems.

This study discovered that clothing size is an important point of consideration when making a clothing purchase for tall female consumers including very tall women more than $175 \mathrm{~cm}$ tall or taller, which is important for Korean SPA brands to develop into a global brand with competitiveness in the international market, where there is the threat of foreign SPA brands. This study found that the taller a woman, the more importantly the clothing size effects, and very tall female consumers $175 \mathrm{~cm}$ tall or taller experience clothing size problems for bottoms length. And existing clothing sizes that focus on average size consumers need to make improvements considering the lengths and shoulder width of tall consumers, and to solve the problem of relation between vertical and horizontal clothing sizes. There is a need to diversify the range and number of sizes in the clothing sizing system, and set a separate tall-size group, or apply the relationship between vertical and horizontal clothing sizes to establish a clothing sizing system. After all, if Korean SPA brands are unable to renew their clothing sizing system even if the number of tall women increases, that will realistically lead to risks in terms of manufacture cost and inventory because of the demand. Clothing companies will need to find an effective solution to increase consumer satisfaction and reduce cost risks.

This study has limitations as a convenience sample was used for the survey to represent women in their twenties, but it extracted points that can be applied to customer-oriented product strategies of Korean and foreign SPA brands. Limited clothing area items were used, but areas general consumers consider important were used, so the results extracted were useful, clear and significant for industrial application. The study has value in that it dealt with clothing sizes of tall women and SPA brands, which have been comparatively neglected as study subjects, and in that it extracted realistic problems by researching clothing sizing systems of products that are actually sold.

With global foreign SPA brands showing signs of launching second brands (Kim, 2014), more intense competition is predicted for the Korean apparel market, and Korean SPA brands are seeking to advance to the Asian market, such as China, after they stabilize in the Korean apparel market, but the Chinese clothing market already has a strong competitive structure due to the strong estab- lishment of global SPA brands ("Chinese SPA market", 2013). In order for Korean SPA brands to have competitiveness not only in Korea but also in the global market, there is a need for a strategic approach that discovers elements that have a decisive effect on purchase preference of local consumers and develops differentiation points for each brand.

\section{Acknowledgments}

This study was supported by the 'BK21 Plus' Project funded by the National Research Foundation of Korea in South Korea.

\section{References}

8seconds. (2013). Size chart. Retrieved December 7, 2013, from http:/ /www.8seconds.co.kr/app.good.GoodAction.getGoodDetail. top?style_no $=2014011795992 \&$ input_type $=57020 \& \mathrm{ctg}$ id $=10043$

Apparel News. (2004, January 19). Global era and global brand 'H\&M' in Sweden. Retrieved Apr 27, 2014, from http:// www.appnews.co.kr/main/pnews.php?table=paper_news\&query =view\&uid=23124\&p=

BNT News. (2013, December 26). Anadieu, 2013! The finishing up by clothing type: Outdoor and SPA brands remain strong. Retrieved April 8, 2014, from http://bntnews.hankyung.com/apps/news?popup $=0 \&$ nid $=02 \& \mathrm{c} 1=02 \& \mathrm{c} 2=02 \& \mathrm{c} 3=00 \&$ nkey $=201312241917173 \&$ mode $=$ sub_view

Bye, E., \& McKinney, E. (2010). Fit analysis using live and 3D scan models. International Journal of Clothing Science and Technology, $22(2 / 3), 88-100$.

Cerviño, J. (1998). Las empresas de distribucion de productos de confeccion. Un Caso de Proyeccion Internacional Distribuciony Consumo, 8(38), 50-67.

'Chinese SPA market'. (2013, April 5). Samsung Design Net. Retrieved April 27, 2014, from http://www.samsungdesign.net

Choi, K. H. (2001). A study on directions of 21 th century fashion distribution through the analysis of successful cases. Proceedings of the Spring Conference on the Costume Culture Association, 2001, pp. 53-54.

Chowdhary, U., \& Beale, N. V. (1988). Plus-size women's clothing interest: Satisfactions and dissatisfactions with ready-to-wear apparel. Perceptual and Motor Skills, 66, 783-788.

Chun-Yoon, J., \& Jasper, C. (1993). Garment-sizing systems: An international comparison. International Journal of Clothing Science and Technology, 5(5), 28-37.

Chun, J. S., \& Noh, Y. J. (2006). A study on a product supply of casual apparel brands -Focused on SPA characteristics-. The Research Journal of the Costume Culture, 15(1), 1-12.

'Consideration of competitiveness reinforcement from the cases of Zara and Marks \& Spencer'. (2004, January 15). Samsung Design Net. Retrieved April 27, 2014, from http://www.samsungdesign.net

Forever21. (2013a). Tops, dresses, outerwear. Retrieved December 8, 2013, from http://www.forever21.co.kr/Forever21/ProductView. aspx?Category=f21_app_woventop\&ProductId=2000105691\&Ro wNum $=11 \&$ ColorCode $=\&$ CurrentPage $=1 \&$ AllYN $=\&$ paramprice 
$=\&$ paramsize $=\&$ paramorder $=1$

Forever21. (2013b). Pants, skirts, jeans. Retrieved December 8, 2013, from http://www.forever21.co.kr/Forever21/ProductView.aspx? Category=f21_app_pants\&ProductId=2000107512\&RowNum=1 $1 \&$ ColorCode $=\&$ CurrentPage $=1 \&$ AllYN $=\&$ paramprice $=\&$ param size $=\&$ paramorder $=$

Gap. (2014). Size chart. Retrieved May 1, 2014, from http://www. gap.com/browse/sizeChart.do?cid=2082\&mlink=85032,6473436, PetiteSizeChart\&clink $=6473436$

Glock, R. E., \& Kunz, G. I. (1990). Apparel manufacturing: Sewn product analysis, New York: Macmillan Publishing Company.

H\&M. (2013). Size guide. Retrieved December 7, 2013, from http:// www.hm.com $/ \mathrm{kr} /$ sizeguide/sizeguide_ladies

Ha, H. J. (2009). An analysis of the present condition of sizing system and fitting on formal pants of the on-line shopping mall for plussized women. Journal of the Korean Society of Costume, 58(1), 133-150.

Han, H. W. (2013, June 25). Korean SPA brands such as 8seconds and Mixxo consider carefully differentiation. Consumer Times. Retrieved November 24, 2013, from http://www.cstimes.com/ news/articleView.html?idxno $=106073$

Jang, J. I. (2004). Selection of on-line and/or channels of the consumers during the purchase decision making process foe apparel. Unpublished master's thesis, Seoul National University, Seoul.

Jones, M. R., \& Giddings, V. L. (2010). Tall women's satisfaction with the fit and style of tall women's clothing. Journal of Fashion Marketing and Management, 14(1), 58-71.

Jung, S. A. (2010). The effects of the VMD of an SPA store on product evaluation and purchase preferences. Unpublished master's thesis, Duksung Women's University, Seoul.

Kang, M. J. (2014, March 3). Nayeong Kim's fashion business: Fashion is not the privilege for the rich. Hankyung Business. Retrieved March 27, 2014, from http://magazine.hankyung.com/ business/apps/news? popup $=0 \&$ nid $=01 \&$ c $1=1005 \&$ nkey $=$ $2014031300953000371 \&$ mode $=$ sub_view

Kersch, E. A. (1984). An investigation of the clothing problems of tall women. Unpublished master's thesis, Virginia Polytechnic Institute and State University, Blacksburg, VA.

Kim, A. R. (1998). A study on sizing system for the competitive manufacturin environment of domestic apparel product -For 18 to 24 years old females -. Journal of Human Life Sciences, 1, 233264.

Kim, B. R. (2014, January 21). Global SPA brands are secondly going to attack Korean apparel market. News Way. Retrieved April 8, 2014, from http://news.newsway.co.kr/view.php?tp=1\&ud= 2014012015075225215\&md=20140121104447_AO

Kim, H, A. (2007). Apparel sizing system for women with obese figure -Focusing on the formal dress for 20 s and 30 s women-. Unpublished doctoral dissertation, Hanyang University, Seoul.

Kim, H. J., \& Lee, S. H. (2007). An analysis of consumers' buying behaviors and the importance of store attributes in SPA brand Focused on female college student in Seoul metropolitan area and Gyeongi-do area-. The Research Journal of the Costume Culture, 15(3), 369-382.

Kim, H. S. (2012). A study on the characteristics of marketing strategy on the SPA brand. Journal of the Korean Fashion \& Costume Design Association, 14(1), 131-150.
Kim, H. S. (2006). Satisfaction with the somatotype \& fit of overweight women's ready-to-wear. Fashion \& Textile Research Journal, 8(1), 64-70.

Kim, J. H., \& Lee, S. Y. (2009). Global SPA brands in the Korean market-The cases of Uniqlo and Zara-. International Business Review, 13(4), 271-297.

Kim, J. Y. (2013, November 8). Korean apparel companies take action against foreign SPA brands's encroaching on the market. SBS CNBC. Retrieved April 8, 2014, from http://sbscnbc.sbs.co.kr/ read.jsp?pmArticleId $=10000607523$

Kim, S. R. (2000). Production model development of mass customized clothing for middle-aged women. Unpublished doctoral dissertation, Ewha Womans University, Seoul.

Knowledge economy terminology dictionary. (2010). SPA Brand. Retrieved November 12, 2013, from http:/terms.naver.com/ entry.nhn?docId $=303712 \&$ cid $=2897 \&$ categoryId $=2897$

Korea Federation of Textile Industries. (2013). Korean market expansion of global SPA brands and counterplan of Korean brands. Retrieved April 8, 2014, from http://www.kofoti.or.kr/OpBoard/ View.asp?Code=IPB\&Page $=2 \&$ Uid $=99$

Korean Agency for Technology and Standards. (2013). Comparison of measurements by year. Retrieved November 24, 2013, from http:/ /sizekorea.kats.go.kr/03_report/yearCompare.asp?OlapCode $=$ SIZU0307

Korean Agency for Technology and Standards. (2010). The 6th Size Korea $3 D$ scan \& measurement technology report. Seoul: Goverment Printing Office.

KS K 0051. (2009). Sizing systems for female adult's garments. Reference no. KS K 0051-2009, Gwacheon: Korean Agency for Technology and Standards.

Lee, E. K. (2010b). A study on environmentally-friendly marketing development plan for fashion industry. Natural Science, 21(1), 83101.

Lee, E. K. (2000). A study on old-age women's body type and apparel size-specifications. Unpublished master's thesis, Konkuk University, Seoul.

Lee, H. S., Kim, H. J., \& Lee, J. G. (2012). A study on the influence of SPA (speciality store retailer of private label Apparel) brand buying experience on brand loyalty. Academy of Customer Satisfaction Management, 14(1), 101-123.

Lee, H. J., \& Jung, S. H. (2010). SPA success strategy 2. Seoul: Fashion Insight.

Lee, H. J., \& Kang, K. Y. (2004). Fashion retailing. Seoul: Kyomunsa.

Lee, H. J. (2014, Apr 8). 'Goalath' Uniqlo is nervous of 'David' 8seconds. Economic Review. Retrieved Apr 8, 2014, from http:// www.econovill.com/archives/175910

Lee, J. H. (2009b). An analysis and case study on current conditions of SPA at home and abroad -With focus on casual apparel-. Unpublished master's thesis, Kokmin University, Seoul.

Lee, J. H. (2010a). Shopping orientations and attitudes according to the collaboration of luxury brands and of fast fashion brand. Unpublished master's thesis, Kokuk University, Seoul.

Lee, J. Y. (2011b). A study on the perceived size related risk and clothing behaviors according to perceived body characteristics and satisfaction with body characteristics -Focus on internet fashion consumers-. Journal of the Korean Society of Clothing and Textiles, 35(5), 575-586. 
Lee, J. Y. (2011a). Body characteristics, perceived body size and bodycathexis for short women aged 18 to 59. Journal of the Korean Society of Clothing and Textiles, 35(1), 1346-1361.

Lee, M. S. (2013). A study of the counter-strategies to the launch of global SPA brands into Korean fashion market. Korea Research Academy of Distribution and Management Review, 16(5), 65-73.

Lee, S. A. (2003). Clothes shopping propensity and satisfaction with clothes of consumers using SPA casual brands-Focused on female university students-. Unpublished master's thesis, Ewha Womans University, Seoul.

Lee, S. A. (2004). Marketing strategy of Korean SPA brands. Journal of Ewha Human Living Environment Institution, 2, 1-15.

Lee, S. M. (1997a). A study on clothing satisfaction of the ready to wear garment for women. Journal of the Korean Society of Costume, 35, 167-180.

Lee, S. M. (2011c). Consumer satisfaction with big-size women's apparel. Unpublished doctoral dissertation, Incheon National University, Incheon.

Lee, S. M. (1997b). Relation between body cathexis and clothing satisfaction. Journal of Hanyang Women's University, 20, 191-207.

Lee, S. Y. (2009a). Korean market expansion strategies of global SPA brands -Zara and Uniqlo-. Unpublished master's thesis, Sookmyung Woman's University, Seoul.

Lee, Y. O. (2002, June). Do Korean SPA distributions get settle? Fashionbiz, pp. 166-172.

Lopez, C., \& Fan, Y. (2009). Internationalisation of the Spanish fashion brand Zara. Journal of Fashion Marketing and Management, 13(2), 279-296.

Min, D. W. (1986). A study on the consumer dissatisfaction in the purchase and use of clothing. Unpublished master's thesis, Seoul National University, Seoul.

Mixxo. (2013). Size chart. Retrieved December 7, 2013, from http:// www.mixxo.com/Style/StyleDetail.aspx?StyleCode= MIYW42411C\&CategoryIdx=2839\&StyleType $=0 \&$ depth=2

Nam, Y. J., Lee, J. Y., \& Choi, Y. K. (2002). A study on the change of body type according to the comparison of 1990 with 1999 . Fashion \& Textile Research Journal, 4(1), 64-70.
Oh, S. Y. (2000). Study on sizing system for women's apparel brands. Unpublished master's thesis, Yonsei University, Seoul.

Onozuka, A. (2002). Uniqlo goes global. Bobbin, 43(9), 18-22.

'Review 2013, preview 2014: 10 issues of fashion industry in 2013 and prospect in 2014'. (2013, December 13). Samsung Design Net. Retrieved April 27, 2014, from http://www.samsungdesign.net

Shim, S., \& Kotsiopulos, A. (1990). Women's physical size, bodycathexis, and shopping for apparel. Perceptual and Motor Skills, 7l(3), 1031-1042.

Sohn, J. S. (2013, May 27). Stop, Gap, Uniqlo, Zara and H\&M! Korean SPA brand is emerging. Aha Economy. Retrieved November 12, 2013, from http://www. ahaeconomy.com/News.aha?method= newsView\&n_id=10691\&cid=15\&pid=1

Spao. (2013). Size chart. Retrieved December 8, 2013, from http:// www.spao.com/shop/product_detail.aspx?PC=SPYA424G34

Suh, H. K., \& Lee, S. H. (2011). Shopping orientation and satisfaction with clothes of 20 s women consumers using domestic/global SPA brands. Journal of the Korean Society of Clothing and Textiles, 35(5), 501-512.

Tex Herald. (2000). Case of foreign SPA -Gap in US. 21 August 2000, 11.

Topten. (2013). Size guide. Retrieved December 7, 2013, from http:// www.topten 10.co.kr/displayDetail/sizeHtmlPopup.lecs

Uniqlo. (2013). Product sizes. Retrieved December 7, 2013, from http:/ /image.uniqlo.kr//goods/31/02/47/57/sizeTable/131144000_size.html

'Uniqlo's second weapon, GU'. (2013, November 11). Samsung Design Net. Retrieved April 27, 2014, from http://www.samsungdesign.net

Yokota, M. (2012). Light and shadow of Uniqlo empire. (Yang, Y. C., Trans.) Seoul: Seoul Media Group New Paradigm of Culture, 8489. (Original work published 2011)

Zara. (2013). Size guide women. Retrieved December 7, 2013, from http://www.zara.com/webapp/wcs/stores/servlet/ProductGuide SizeAjaxView?langId=-1\&productId=1050083\&storeId=10706

(Received 3 December 2014; 1st Revised 9 January 2015; 2nd Revised 28 April 2015; Accepted 30 April 2015)

C 2015 (by) the authors. This article is an open access article distributed under the terms and conditions of the Creative Commons Attribution license (http://creativecommons.org/licenses/by/3.0/), which permits unrestricted use, distribution, and reproduction in any medium, provided the original work is properly cited. 